\title{
Bradykinin and adenosine receptors mediate desflurane induced postconditioning in human myocardium: role of reactive oxygen species
}

\author{
Sandrine Lemoine ${ }^{1 *}$, Clément Buléon ${ }^{2}$, René Rouet ${ }^{1}$, Calin Ivascau ${ }^{3}$, Gérard Babatasi ${ }^{3}$, Massimo Massetti ${ }^{3}$, \\ Jean-Louis Gérard ${ }^{1,2}$, Jean-Luc Hanouz ${ }^{1,2}$
}

\begin{abstract}
Background: Desflurane during early reperfusion has been shown to postcondition human myocardium, in vitro. We investigated the role of adenosine and bradykinin receptors, and generation of radical oxygen species in desflurane-induced postconditioning in human myocardium.

Methods: We recorded isometric contraction of human right atrial trabeculae hanged in an oxygenated Tyrode's solution (34 degrees Celsius, stimulation frequency $1 \mathrm{~Hz}$ ). After a 30-min hypoxic period, desflurane 6\% was administered during the first 5 min of reoxygenation. Desflurane was administered alone or with pretreatment of $\mathrm{N}$-mercaptopropionylglycine, a reactive oxygen species scavenger, 8-(p-Sulfophenyl)theophylline, an adenosine receptor antagonist, HOE140, a selective B2 bradykinin receptor antagonist. In separate groups, adenosine and bradykinin were administered during the first minutes of reoxygenation alone or in presence of $\mathrm{N}$ mercaptopropionylglycine. The force of contraction of trabeculae was recorded continuously. Developed force at the end of a 60-min reoxygenation period was compared (mean \pm standard deviation) between the groups by a variance analysis and post hoc test.

Results: Desflurane $6 \%$ (84 $\pm 6 \%$ of baseline) enhanced the recovery of force after 60-min of reoxygenation as compared to control group (51 $\pm 8 \%$ of baseline, $P<0.0001$ ). $N$-mercaptopropionylglycine (54 $\pm 3 \%$ of baseline), 8-(p-Sulfophenyl)theophylline (62 $\pm 9 \%$ of baseline), HOE140 (58 $\pm 6 \%$ of baseline) abolished desflurane-induced postconditioning. Adenosine ( $80 \pm 9 \%$ of baseline) and bradykinin ( $83 \pm 4 \%$ of baseline) induced postconditioning $(P<0.0001$ vs control), $N$-mercaptopropionylglycine abolished the beneficial effects of adenosine and bradykinin (54 \pm 8 and $58 \pm 5 \%$ of baseline, respectively).
\end{abstract}

Conclusions: In vitro, desflurane-induced postconditioning depends on reactive oxygen species production, activation of adenosine and bradykinin $B_{2}$ receptors. And, the cardioprotective effect of adenosine and bradykinin administered at the beginning of reoxygenation, was mediated, at least in part, through ROS production.

\section{Background}

Anesthetic-induced postconditioning (PostC) is a phenomenon whereby a brief exposure of the myocardium to a volatile halogenated anesthetic, at the very onset of reperfusion, markedly reduces myocardial injury following prolonged ischemia: anesthetic-induced PostC has

\footnotetext{
* Correspondence: sand.lemoine2@wanadoo.fr

'Laboratory of Experimental Anesthesiology and Cellular Physiology, IFR 146 ICORE, Université de Caen Basse Normandie, CHU Caen, Avenue de la Cote de Nacre, 14033 Caen, France
}

been confirmed in several mammalian species including rat, mouse, rabbit, and human [1-8].

The mechanism of volatile anesthetic-induced decrease of reperfusion injury remains incompletely understood. Endogenous activation of opioids, bradykinin, and adenosine receptors can trigger the complex protective signalling pathway of ischemic PostC [9]. It has been shown that adenosine and bradykinin postconditioned isolated rabbit [10] and rat hearts [11], via stimulation of adenosine and $\mathrm{B}_{2}$ receptors. At present, the involvement of adenosine and bradykinin receptors in 
anesthetic-induced PostC remains unknown, whereas these receptors were shown to be involved in anesthetic-induced preconditioning [12]. On the other hand, several studies showed that volatile anesthetic triggered intracellular reactive oxygen species (ROS) production [13], and that ROS production may mediate and/or trigger the preconditioning signalling cascade. Thus, sevoflurane and desflurane-induced preconditioning were abolished by ROS scavengers [14]. However, only two studies suggested that ROS were involved in isofluraneinduced PostC in mouse myocardium in vivo [3], and in sevoflurane-induced PostC in isolated rat hearts [8].

The objectives of our study were to determine whether: 1) ROS generation, and adenosine and bradykinin receptor stimulation may be involved in desfluraneinduced PostC, 2) adenosine and bradykinin given at the beginning of reoxygenation mimic PostC, 3) adenosine and bradykinin receptors' activation was followed by myocardial PostC via ROS production.

\section{Methods}

After the approval of local medical ethics committee (Comité de Protection des Personnes Nord Ouest III, Caen, France) and written informed consent, right atrial appendages were obtained during cannulation for cardiopulmonary bypass from patients scheduled for routine coronary artery bypass surgery or aortic valve replacement. All patients received total intravenous anesthesia with propofol, remifentanil, and pancuronium. Patients with chronic atrial arrhythmia and with diabetes mellitus treated with insulin or oral hypoglycemic agents were excluded from the study $[7,14]$.

\section{Experimental conditions}

Right atrial trabeculae (one or two per appendage) were dissected and suspended vertically between an isometric force transducer (MLT0202, ADInstruments, Sydney, Australia) and a stationary stainless clip in a $200 \mathrm{ml}$ organ bath filled with daily prepared Tyrode's modified solution containing $(\mathrm{mM}) 120 \mathrm{NaCl}, 3.5 \mathrm{KCl}, 1.1 \mathrm{MgCl}_{2}$, $1.8 \mathrm{NaH}_{2} \mathrm{PO}_{4}, 25.7 \mathrm{NaHCO}_{3}, 2.0 \mathrm{CaCl}_{2}$, and 5.5 glucose. The organ bath was maintained at $34^{\circ} \mathrm{C}$ by a thermostatic water circulator (Polystat micropros, Bioblock, Illkirch, France). The bathing solution was insufflated with carbogen $\left(95 \% \mathrm{O}_{2}-5 \% \mathrm{CO}_{2}\right)$, resulting in a $\mathrm{pH}$ of 7.40 and a partial pressure of oxygen of $600 \mathrm{~mm} \mathrm{Hg}$. Isolated muscles were field-stimulated at $1 \mathrm{~Hz}$ by two platinum electrodes with rectangular wave pulses of $5 \mathrm{~ms}$ duration 20\% above threshold (CMS 95107, Bionic Instrument, Paris, France).

Trabeculae were equilibrated for 60 to $90 \mathrm{~min}$ to allow stabilization of their optimal mechanical performance at the apex of the length-active isometric tension curve $\left(\mathrm{L}_{\max }\right)$. At the end of the stabilization period, trabeculae were randomized to experimental groups detailed below. The force developed was measured continuously, digitized at a sampling frequency of $400 \mathrm{~Hz}$, and stored on a Writable Compact Disc for analysis (MacLab, AD Instrument, Sydney, Australia).

At the end of each experiment, the length and the weight of the muscle were measured. The muscle crosssectional area was calculated from its weight and length assuming a cylindrical shape and a density of 1 . To avoid core hypoxia, trabeculae included in the study should have a cross-sectional area less than $1.0 \mathrm{~mm}^{2}$, a force of contraction normalized per cross-sectionnal area $(\mathrm{FoC})>5.0 \mathrm{mN} / \mathrm{mm}^{2}$ and a ratio of resting force/ total force less than 0.45 .

\section{Experimental protocol}

In all groups, hypoxia-reoxygenation was performed by replacing $95 \% \mathrm{O}_{2}-5 \% \mathrm{CO}_{2}$ with $95 \% \mathrm{~N}_{2}-5 \% \mathrm{CO}_{2}$ in the buffer for 30-min, followed by a 60 -min oxygenated recovery period.

In the Control group (Control; $\mathrm{n}=8$ ) muscles were exposed to the hypoxia-reoxygenation protocol alone. In the desflurane treatment groups, desflurane was delivered to the organ bath by the gas flow passing through a specific calibrated vaporizer. Desflurane concentration in the carrier gas phase was measured with an infrared calibrated analyzer (Capnomac, Datex, Helsinki, Finland). Desflurane was administered at 6\% (Desflurane 6\%; $n=$ 6) during the first $5 \mathrm{~min}$ of reoxygenation (fig. 1).

Mechanisms involved in desflurane-induced PostC were studied in presence of desflurane $6 \%$, because we have previously shown that $6 \%$ was effective to induce PostC in human myocardium, in vitro. ${ }^{7}$ In separate groups exposed to $6 \%$ desflurane during the first 5-min of reoxygenation in the presence of $150 \mu \mathrm{M} N$-mercaptopropionylglycine, a ROS scavenger (Des + MPG; $\mathrm{n}=$ 6), $100 \mu \mathrm{M} 8$-(p-Sulfophenyl)theophylline, an adenosine receptor antagonist (Des + SPT; $\mathrm{n}=6), 20 \mathrm{nM}$ HOE140, a selective $B_{2}$ bradykinin receptor antagonist $($ Des + HOE; $n=6)$. Pharmacological agents were administered $5 \mathrm{~min}$ before, throughout, and $10 \mathrm{~min}$ after desflurane administration (fig. 1).

The effect of MPG, SPT, and HOE140 alone was studied in separate groups exposed to $150 \mu \mathrm{M} \mathrm{N}$ mercaptopropionylglycine (MPG; $n=6), 100 \mu \mathrm{M} 8$ (p-Sulfophenyl)theophylline (SPT; $\mathrm{n}=6$ ), $20 \mathrm{nM}$ HOE140 (HOE; $\mathrm{n}=6$ ), $5 \mathrm{~min}$ before and during the first $15 \mathrm{~min}$ of reoxygenation (fig. 1).

\section{Sequence of activation of adenosine and bradykinin receptors and ROS generation}

In separate experimental groups, trabeculae were randomly assigned to receive 1) $100 \mu \mathrm{M}$ adenosine alone, in the 15 first min of reoxygenation (adenosine (ADO) 


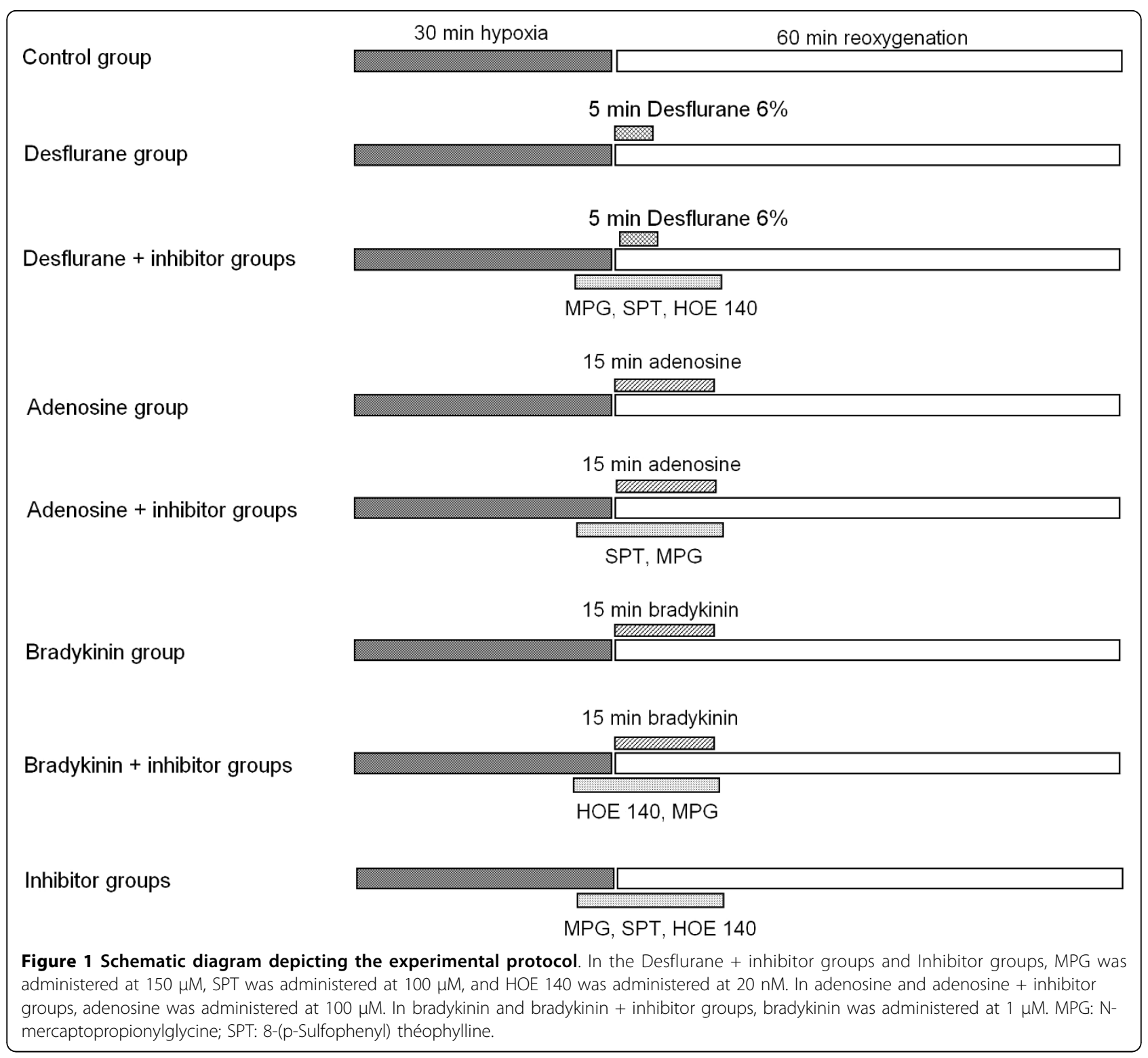

group; $\mathrm{n}=6$ ), or 2) co-superfused with pre-treatment ( $5 \mathrm{~min}$ before and $15 \mathrm{~min}$ after reoxygenation) with 100 $\mu \mathrm{M}$ SPT (ADO + SPT; $\mathrm{n}=6)$, or 3) with $150 \mu \mathrm{M}$ MPG $(\mathrm{ADO}+$ MPG; $\mathrm{n}=6)$ (fig. 1).

In 3 other separate experimental groups, trabeculae were randomly assigned to receive: 1) $1 \mu \mathrm{M}$ bradykinin alone, in the 15 first min of reoxygenation (BK group; $\mathrm{n}=6$ ), or 2) co-superfused with pre-treatment (5 min before and $15 \mathrm{~min}$ after reoxygenation) with $20 \mathrm{nM}$ HOE140 (BK + HOE; $\mathrm{n}=6)$, or 3) with $150 \mu \mathrm{M}$ MPG $(\mathrm{BK}+\mathrm{MPG} ; \mathrm{n}=6)$ (fig. 1).

The concentrations of inhibitors MPG [14], SPT [10], HOE 140 [11], and activators adenosine [10], bradykinin [15] used here have been validated in previous experimental studies, in vitro.

\section{Chemicals}

MPG and adenosine were purchased from Calbiochem (VWR International, Fontenay sous Bois, France) and bradykinin, HOE 140, SPT were obtained from Sigma Aldrich (Saint Quentin Fallavier, France). Desflurane was purchased from GlaxoWellcome (Marly-le-Roi, France).

\section{Statistical Analysis}

The endpoint of the study was the recovery of FoC at 60 min of reoxygenation $\left(\mathrm{FoC}_{60}\right.$, expressed as percent of baseline). All values were compared by ANOVA with application of a post hoc Bonferroni test. Power analysis calculated a group size of $\mathrm{n}=5$ to detect a difference of $40 \%$ in $\mathrm{FoC}$ (Control and inhibitors group: $\mathrm{FoC}_{60}=50$ 
$\pm 9 \%$ of baseline, and Desflurane 6\% group: $\mathrm{FoC}_{60}=90 \pm$ $9 \%$ of baseline) with a power of 0.8 at alpha-level of 0.05 . The number of experiments per group was calculated based on an one-way analysis of variance (ANOVA) with 4. Control and inhibitors groups and 1 desflurane 6\% group. Data are expressed as mean \pm SD. Baseline values of main mechanical parameters, age, preoperative left ventricular ejection fraction, and $\mathrm{FoC}_{60}$ were compared by univariate analysis of variance with group factor as the independent variable. If the $P$ value was less than 0.05 , a Bonferroni post hoc analysis was performed. Within-group data were analyzed over time using two way analysis of variance for repeated measures and Bonferroni post hoc analysis with group factor and time (baseline, hypoxia 5 , $10,20,30 \mathrm{~min}$, and reoxygenation $5,10,20,30,40,50$, and $60 \mathrm{~min}$ ) as independent variables.

\section{Results}

There were no differences between groups for patients' demographic data, preoperative treatments, and left ventricular ejection fraction (Table 1). Eighty six human right atrial trabeculae were studied. There were no differences in baseline values for $L_{\max }$, cross-sectionnal area, ratio of resting force to total force, and $\mathrm{FoC}$ between groups (Table 2).

\section{Effects of desflurane on hypoxia reoxygenation on human atrial trabeculae}

In the Control group, reoxygenation resulted in a partial recovery of $\mathrm{FoC}\left(\mathrm{FoC}_{60}: 51 \pm 8 \%\right.$ of baseline). Desflurane increased the $\mathrm{FoC}_{60}$ as compared to Control group $\left(\mathrm{FoC}_{60}\right.$ : $84 \pm 6 \%$ of baseline vs. Control; $P<0.0001$ ) (fig. 2 ).

Effects of N-mercaptopropionylglycine, 8-(p-Sulfophenyl) theophylline and HOE 140 in desflurane treated preparations

Desflurane-induced enhanced recovery of $\mathrm{FoC}$ at the end of reoxygenation was abolished $(P<0.0001)$ in presence of MPG ( $\mathrm{FoC}_{60}: 54 \pm 3 \%$ of baseline), SPT ( $\mathrm{FoC}_{60}: 62 \pm$ 9\% of baseline), $\mathrm{HOE} 140$ ( $\mathrm{FoC}_{60}: 58 \pm 6 \%$ of baseline).

As compared to the control group (control: $51 \pm 8 \%$ of baseline), MPG alone (MPG: $56 \pm 2 \%$ of baseline;

Table 1 Patients demographic data, preoperative drug treatments, and preoperative left ventricular ejection fraction

\begin{tabular}{|c|c|c|c|}
\hline Groups and heart disease & Age $(\mathrm{Yr})$ & Preoperative drug treatments & LVEF(\%) \\
\hline $\begin{array}{l}\text { Control } \\
\operatorname{AVR}(n=2) ; \operatorname{CABG}(n=6)\end{array}$ & $66 \pm 7$ & ACE (3), $\beta A B(5), B Z D(1), C A(0), C O R(0), F U R(1), M O L(0), \operatorname{STA}(5), N T(0)$ & $73 \pm 11$ \\
\hline $\begin{array}{l}\text { Desflurane } \\
\text { AVR }(n=1) ; \operatorname{CABG}(n=5)\end{array}$ & $67 \pm 9$ & ACE (2), $\beta A B(5), B Z D(0), C A(1), C O R(0), F U R(0), M O L ~(1), S T A(4), N T(0)$ & $64 \pm 19$ \\
\hline $\begin{array}{l}\text { Des + MPG } \\
\text { AVR }(n=3) ; \text { CABG }(n=3)\end{array}$ & $64 \pm 12$ & $\operatorname{ACE}(2), \beta A B(3), B Z D(1), C A(1), C O R(0), F U R(0), M O L(0), S T A(1), N T(0)$ & $71 \pm 21$ \\
\hline $\begin{array}{l}\text { Des + SPT } \\
\text { AVR }(n=4) ; \text { CABG }(n=2)\end{array}$ & $66 \pm 21$ & ACE (3), $\beta A B(3), B Z D(2), C A(0), C O R(0), F U R(0), M O L ~(1), S T A(1), N T(0)$ & $67 \pm 10$ \\
\hline $\begin{array}{l}\text { Des }+ \text { HOE } \\
\text { AVR }(n=2) ; \text { CABG }(n=4)\end{array}$ & $69 \pm 8$ & 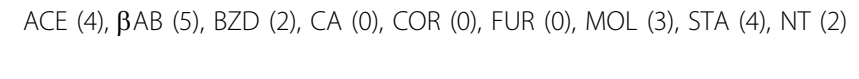 & $59 \pm 2$ \\
\hline $\begin{array}{l}\operatorname{ADO} \\
\operatorname{AVR}(n=1) ; \operatorname{CABG}(n=5)\end{array}$ & $70 \pm 8$ & $\operatorname{ACE}(2), \beta A B(2), B Z D(0), C A(1), C O R(0), F U R(0), M O L(0), \operatorname{STA}(4), N T(0)$ & $65 \pm 10$ \\
\hline $\begin{array}{l}\mathrm{ADO}+\mathrm{SPT} \\
\operatorname{AVR}(\mathrm{n}=3) ; \mathrm{CABG}(\mathrm{n}=3)\end{array}$ & $55 \pm 11$ & ACE (4), $\beta A B(4), B Z D(1), C A(2), C O R(0), F U R(1), M O L(0), \operatorname{STA}(2), N T(0)$ & $60 \pm 12$ \\
\hline $\begin{array}{l}A D O+M P G \\
A V R(n=2) ; C A B G(n=4)\end{array}$ & $73 \pm 9$ & ACE (3), $\beta A B(2), B Z D(3), C A(0), C O R(0), F U R(0), M O L(0), S T A(3), N T(0)$ & $73 \pm 6$ \\
\hline $\begin{array}{l}\operatorname{BK} \\
\operatorname{AVR}(n=5) ; \operatorname{CABG}(n=1)\end{array}$ & $67 \pm 11$ & $\operatorname{ACE}(3), \beta A B(3), B Z D(2), C A(2), C O R(0), F U R(0), M O L(0), \operatorname{STA}(6), N T(0)$ & $59 \pm 15$ \\
\hline $\begin{array}{l}\mathrm{BK}+\mathrm{HOE} \\
\operatorname{AVR}(n=4) ; \mathrm{CABG}(n=2)\end{array}$ & $60 \pm 15$ & 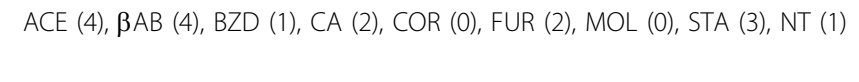 & $65 \pm 16$ \\
\hline $\begin{array}{l}\mathrm{BK}+\mathrm{MPG} \\
\mathrm{AVR}(\mathrm{n}=3) ; \mathrm{CABG}(\mathrm{n}=3)\end{array}$ & $66 \pm 17$ & ACE (2), $\beta A B(1), B Z D(2), C A(0), C O R(0), F U R(1), M O L(0), S T A(3), N T(0)$ & $61 \pm 9$ \\
\hline $\begin{array}{l}\text { MPG } \\
\operatorname{AVR}(n=5) ; \operatorname{CABG}(n=1)\end{array}$ & $71 \pm 2$ & ACE (4), $\beta A B(2), B Z D(2), C A(0), C O R(0), F U R(0), M O L(0), S T A(5), N T(0)$ & $71 \pm 9$ \\
\hline $\begin{array}{l}\text { SPT } \\
\text { AVR }(n=5) ; \operatorname{CABG}(n=1)\end{array}$ & $68 \pm 15$ & ACE (2), $\beta A B(2), B Z D(0), C A(0), C O R(0), F U R(2), M O L(0), \operatorname{STA}(2)$, TNT (0) & $74 \pm 8$ \\
\hline $\begin{array}{l}\mathrm{HOE} \\
\operatorname{AVR}(n=0) ; \operatorname{CABG}(n=6)\end{array}$ & $66 \pm 10$ & ACE (5), $\beta A B(4), B Z D(2), C A(2)$ COR (0), FUR (0), MOL (2), STA (4), NT (3) & $70 \pm 9$ \\
\hline
\end{tabular}

The number in brackets after heart disease and drug abbreviation indicate the number of patients. Age and LVEF are expressed as mean \pm SD. ACE: angiotensin-converting enzyme inhibitors; ADO: adenosine; AVR: aortic valve replacement; $\beta$ AB: $\beta$-adrenergic blocking drugs; BK: bradykinin; BZD: benzodiazepine; CA: calcium channel antagonists; CABG: coronary artery bypass graft; COR: amiodarone; Des: desflurane; FUR: furosemide; HOE: HOE 140; LVEF: preoperative left ventricular ejection fraction; MOL: molsidomine; MPG: N-mercaptopropionylglycine; NT: nitroglycerin; SPT: 8-(p-Sulfophenyl) théophylline; STA: statins.

Data are mean \pm SD. 
Table 2 Control values of main mechanical parameters of human right atrial trabeculae

\begin{tabular}{|c|c|c|c|c|}
\hline Experimental Groups & $\mathrm{L}_{\max }(\mathrm{mm})$ & $\mathrm{CSA}\left(\mathrm{mm}^{2}\right)$ & $\begin{array}{c}\text { FoC } \\
\left(\mathrm{mN} \cdot \mathrm{mm}^{-2}\right)\end{array}$ & $\mathrm{RF} / \mathrm{TF}$ \\
\hline Control $(n=8)$ & $6.8 \pm 0.6$ & $0.49 \pm 0.10$ & $24 \pm 4$ & $0.33 \pm 0.03$ \\
\hline Desflurane $(n=6)$ & $6.5 \pm 0.7$ & $0.56 \pm 0.07$ & $25 \pm 3$ & $0.30 \pm 0.04$ \\
\hline Des + MPG $(n=6)$ & $7.5 \pm 0.6$ & $0.56 \pm 0.03$ & $23 \pm 5$ & $0.27 \pm 0.04$ \\
\hline Des + SPT $(n=6)$ & $6.0 \pm 0.6$ & $0.54 \pm 0.06$ & $23 \pm 3$ & $0.28 \pm 0.02$ \\
\hline Des + HOE $(n=6)$ & $5.8 \pm 0.4$ & $0.46 \pm 0.04$ & $25 \pm 3$ & $0.34 \pm 0.04$ \\
\hline $\operatorname{ADO}(n=6)$ & $7.7 \pm 0.8$ & $0.59 \pm 0.07$ & $27 \pm 2$ & $0.28 \pm 0.03$ \\
\hline$A D O+S P T(n=6)$ & $6.1 \pm 0.4$ & $0.60 \pm 0.05$ & $25 \pm 3$ & $0.24 \pm 0.02$ \\
\hline$A D O+\operatorname{MPG}(n=6)$ & $6.8 \pm 0.9$ & $0.44 \pm 0.09$ & $22 \pm 4$ & $0.40 \pm 0.04$ \\
\hline BK $(n=6)$ & $5.8 \pm 0.5$ & $0.39 \pm 0.06$ & $28 \pm 4$ & $0.31 \pm 0.04$ \\
\hline $\mathrm{BK}+\mathrm{HOE}(\mathrm{n}=6)$ & $5.1 \pm 0.4$ & $0.54 \pm 0.07$ & $22 \pm 2$ & $0.29 \pm 0.05$ \\
\hline$B K+M P G(n=6)$ & $6.0 \pm 0.4$ & $0.40 \pm 0.04$ & $23 \pm 2$ & $0.31 \pm 0.03$ \\
\hline$M P G(n=6)$ & $6.3 \pm 0.7$ & $0.47 \pm 0.11$ & $30 \pm 1$ & $0.33 \pm 0.06$ \\
\hline SPT $(n=6)$ & $6.6 \pm 0.5$ & $0.54 \pm 0.06$ & $26 \pm 3$ & $0.29 \pm 0.03$ \\
\hline $\operatorname{HOE}(n=6)$ & $5.3 \pm 0.53$ & $0.40 \pm 0.05$ & $26 \pm 4$ & $0.34 \pm 0.04$ \\
\hline
\end{tabular}

$\mathrm{L}_{\text {max }}$ : maximal length at the apex of the length-active force curve; CSA: cross sectionnal area; FoC: Force of contraction normalized per cross sectionnal area; RF/ TF: ratio of resting force on total force. Data are mean $\pm S D$.

ADO: adenosine, BK: bradykinin, Des: desflurane, HOE: HOE 140, MPG: N-mercaptopropionylglycine, SPT: 8-(p-Sulfophenyl) théophylline.

$P=0.08)$, SPT alone (SPT: $59 \pm 3 \%$ of baseline; $P=$ 0.06), and HOE 140 alone (HOE 140: $54 \pm 7 \%$ of baseline; $P=0.29$ ) did not significantly modify $\mathrm{FoC}_{60}$ (fig. 2 ).

\section{Effects of adenosine and bradykinin on hypoxia reoxygenation}

Administration of adenosine and bradykinin, during the first $15 \mathrm{~min}$ of the reoxygenation period, significantly increased the recovery of $\mathrm{FoC}_{60}$ as compared to the control group $(80 \pm 9 \%$ of baseline in adenosine group and $83 \pm 4 \%$ of baseline in bradykinin group; vs. Control group, $P<0.0001)$. Recovery of $\mathrm{FoC}_{60}$ measured in presence of adenosine or bradykinin were similar to that measured in Desflurane group (respectively $P=0.37$ and $P=0.74 v$ s. desflurane group) (fig. 3 ).

\section{Effects of 8-(p-Sulfophenyl)theophylline and N-} mercaptopropionylglycine on adenosine administration The effect of adenosine on $\mathrm{FoC}_{60}$ was abolished by pretreatment with SPT $\left(\mathrm{FoC}_{60}: 53 \pm 8 \%\right.$ of baseline), and with MPG ( $\mathrm{FoC}_{60}: 54 \pm 8 \%$ of baseline $)(P<0.0001 v s$. adenosine group) (fig. 3).

\section{Effects of HOE 140 and N-mercaptopropionylglycine on bradykinin administration}

The enhanced recovery of $\mathrm{FoC}_{60}$ induced by bradykinin was abolished by the pre-treatment with HOE140 (48 \pm $8 \%$ of baseline), and with MPG (55 $\pm 3 \%$ of baseline) $(P<0.0001 v s$. bradykinin group) (fig. 3).

\section{Discussion}

In the present study, we showed that the cardioprotection triggered by desflurane during early reoxygenation involved ROS generation, and stimulation of adenosine and bradykinin $B_{2}$ receptors. Furthermore, adenosine and bradykinin-induced PostC involved at least in part, ROS production.

The present study shows that administration of MPG abolished desflurane-induced PostC in human myocardium, in vitro. These results strongly suggest that desflurane-induced PostC involved ROS production. At present, only two studies have shown, in mouse and rat heart, that isoflurane and sevoflurane-induced PostC was abolished by treatment with ROS scavengers $[3,8]$. In contrast, numerous studies have shown that ROS play a fundamental role in anesthetic-induced preconditioning $[14,16]$. Müllenheim et al. demonstrated that ROS scavengers, blocked the reduction in myocardial infarct size resulting from isoflurane-induced preconditioning [16]. Isoflurane-induced preconditioning was mediated by ROS generated from electron transport chain complex III, in rabbit heart [17]. Moreover, in ventricular myocytes volatile anesthetics inhibit complex I of the electron transport chain [18], and, ROS mediated the mitochondrial uncoupling induced by desflurane treatment [19]. Tanaka et al. reported that mitochondrial adenosine triphosphate-sensitive potassium ( mitoK $_{\mathrm{ATP}}$ ) channel opening triggered isoflurane-induced preconditioning via ROS generation, in rabbit in vivo [20]. We have previously shown that opening of mitoK $\mathrm{K}_{\mathrm{ATP}}$ was an essential step of desflurane-induced PostC in human myocardium [7]. Thus, it could be hypothesized that desflurane-induced PostC generates ROS via mitoK $\mathrm{K}_{\mathrm{ATP}}$ channels opening. Further studies are required to examine the exact relationship between mitoK $\mathrm{K}_{\mathrm{ATP}}$ channel opening and ROS generation during early reperfusion. 


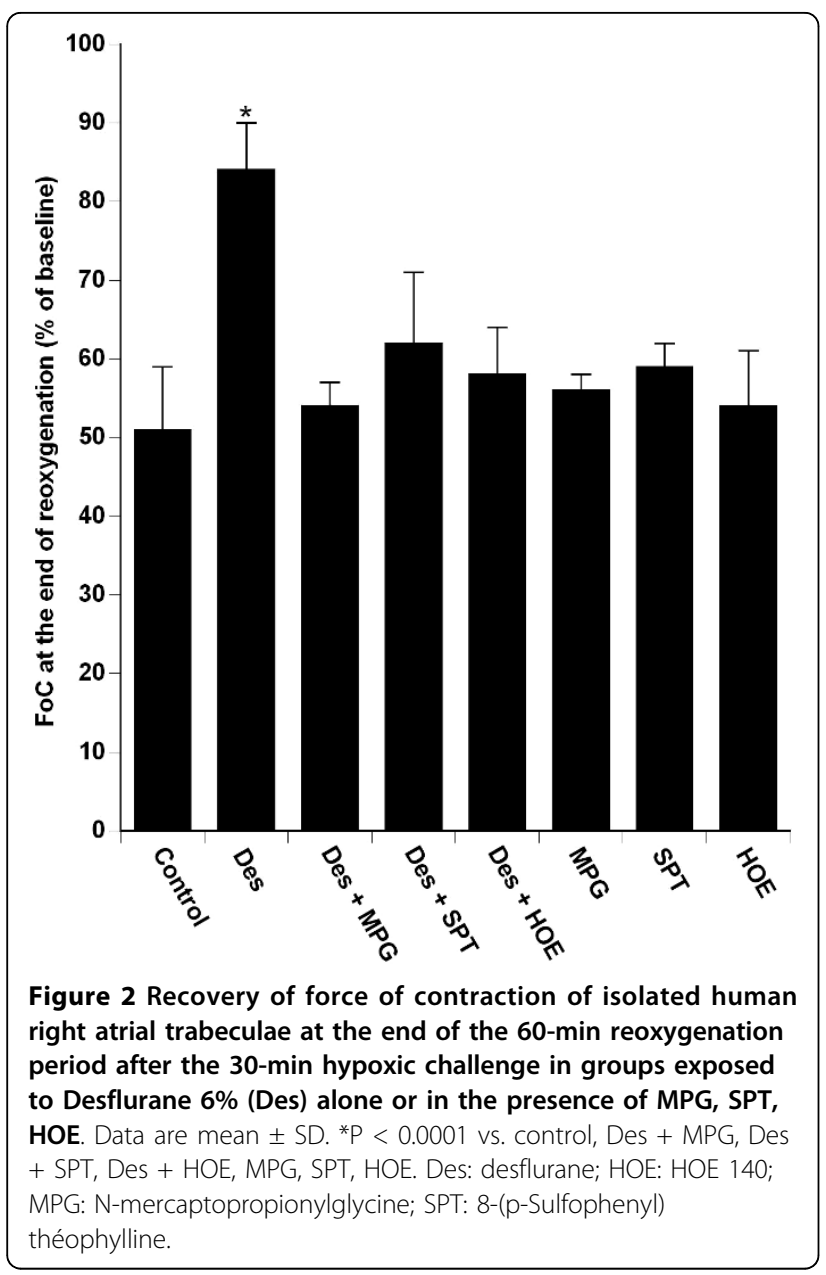

The role of adenosine and bradykinin receptors' stimulation in desflurane-induced PostC was studied here for the first time using human myocardium. The present results show that both adenosine and $B_{2}$ bradykinin receptors' stimulation are involved in desflurane-induced PostC. Pre-treatment with adenosine receptors inhibitor (SPT) and specific $\mathrm{B}_{2}$ bradykinin receptor' inhibitor (HOE140) abolished desflurane-induced PostC. Similarly, the beneficial effects of ischemic PostC were abolished by SPT, in rat and rabbit hearts $[10,21,22]$. Penna et $a l$. showed that HOE 140 infusion eliminated the cardioprotective effect induced by ischemic PostC, in isolated rat hearts [11]. Additionally, a growing body of evidence supports the concept that anesthetic PostC triggers a cardioprotective cascade of molecular signalling events similar to that of ischemic PostC [23]. Then, previous studies showed specific involvement of $\mathrm{A}_{2 \mathrm{~A}}$ and $A_{3}$ adenosine receptors in ischemic PostC in mouse $[10,24]$, and $A_{1}, A_{2 B}$ adenosine receptors in rabbit heart, in vitro $[25,26]$. Using gene knockout mice, it has been shown that ischemic PostC-induced decreased in infarct volume was triggered by activation of adenosine $A_{1}$ and

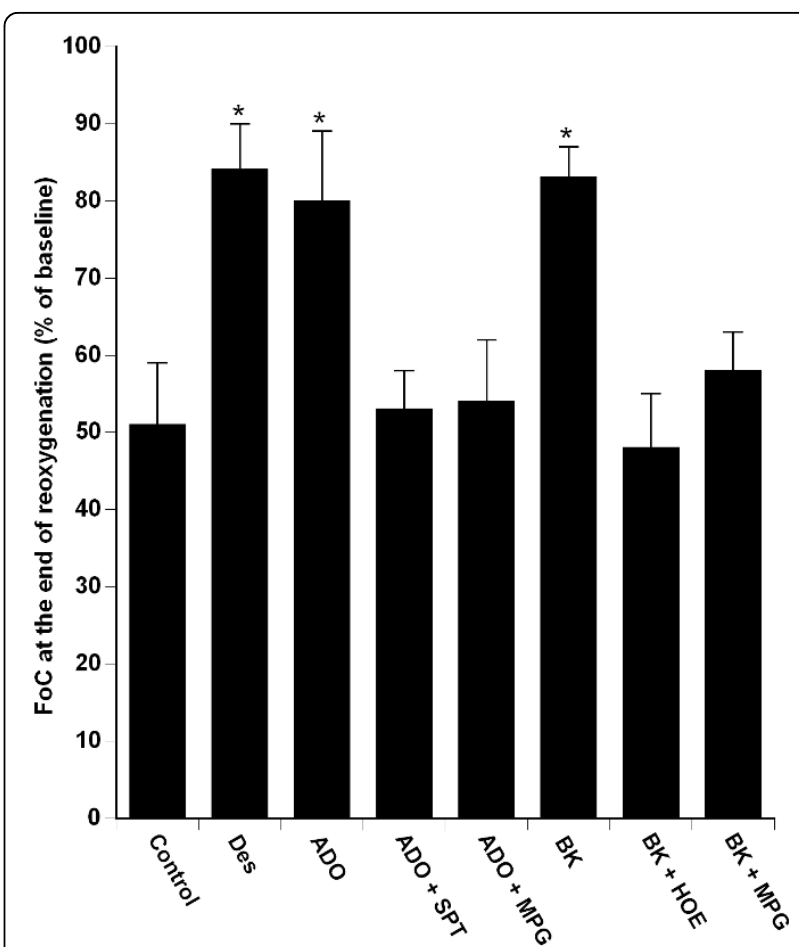

Figure 3 Recovery of force of contraction of isolated human right atrial trabeculae at the end of the $60-\mathrm{min}$ reoxygenation period after the 30-min hypoxic challenge in groups exposed to Desflurane 6\% (Des) alone, exposed to adenosine (ADO) alone or in presence of SPT, MPG; exposed to bradykinin (BK) alone or in presence of HOE, MPG. Control and Des groups are the same that presented in figure 2 . Data are mean \pm SD. ${ }^{*} P<$ 0.0001 vs. control, $\mathrm{ADO}+\mathrm{SPT}, \mathrm{ADO}+\mathrm{MPG}, \mathrm{BK}+\mathrm{HOE}, \mathrm{BK}+\mathrm{MPG}$. ADO: adenosine, BK: bradykinin; Des: desflurane; HOE: HOE 140; MPG: N-mercaptopropionylglycine; SPT: 8-(p-Sulfophenyl) théophylline.

bradykinin $B_{2}$ receptors [27]. In contrast, with anesthetic-induced PostC, the involvement of adenosine receptors (specifically the $A_{1}$ adenosine receptors) stimulation in isoflurane-induced preconditioning has been established [28-30].

Then, we showed that activation of adenosine and bradykinin receptors (via administration of adenosine or bradykinin), at the onset of reoxygenation, enhanced the recovery of $\mathrm{FoC}_{60}$ as compared to the control group. $\mathrm{Lu}$ et al, in rat ventricular myocytes, showed that adenosine-induced PostC was mediated by stimulation of adenosine $A_{1}$ receptors as suggested by abolition of cardioprotective effect of adenosine in presence of 1,3dipropyl-8-cyclopentylxanthine (DPCPX) as $\mathrm{A}_{1}$ adenosine receptor antagonist [31]. Nevertheless, Penna et al. showed that a 3-min administration of adenosine at the beginning of reperfusion did not decrease infarct volume in isolated rat hearts [21]. This discrepancy may result from differences in adenosine concentration between studies (i.e. $30 \mu \mathrm{M}$ in Penna's study vs $100 \mu \mathrm{M}$ in Lu's 
study and our own) and from the brief administration which may be ineffective to stimulate adenosine receptors. Thus, Penna et al showed that a 40 min administration of adenosine during reperfusion was necessary to decrease infarct size [21]. In another study, Penna et al have shown, in isolated rat hearts, that brief repetitive administration of bradykinin during early reperfusion could trigger PostC, whereas continuous administration in the same period wasn't cardioprotective [11].

Our data showed that pretreatment by HOE 140 abolished bradykinin effects, suggesting that bradykinin effects at the beginning of reoxygenation were mediated by the specific stimulation of $B_{2}$ receptors, in accordance with Penna's data [11]. Although the exact mechanism by which adenosine and bradykinin protect human myocardium in vitro is still unknown, studies based on animal models have suggested that ROS may mediate PostC [11]. Our data show that MPG abolished adenosine- and bradykinin-induced post $C$, suggesting that adenosine and bradykinin receptors' activation triggered PostC, at least in part, via ROS generation during early reoxygenation. In addition to ROS production, it has been shown that activation of adenosine and bradykinin receptors during reperfusion may promote mito$\mathrm{K}_{\mathrm{ATP}}$ channels opening [11,31], activation of the RISK pathway including pro survival PI3K/Akt and MEK/ERK $1 / 2$ pathways, p70s6 K activation $[15,32,33]$, and phosphorylation of GSK-3 $\beta$, and prevent the mPTP opening, in rat ventricular myocytes and in isolated rat heart $[34,35]$ These signalling steps have been shown to be involved in ischemic and anesthetic induced PostC. Nevertheless, one study showed that preconditioning triggered by adenosine did not include ROS signaling in isolated rabbit heart [36].

Finally, enhanced recovery of force of human atrial trabeculae after exposure to desflurane, adenosine and bradykinin may suggest an anti-stunning effect of PostC. Whereas PostC reduced infarct size, it does not protect against myocardial stunning in dogs and rabbits [37], moreover post-ischemic systolic function was not modify by ischemic PostC and adenosine as compared to control group in isolated rat heart [21]. Definitely, our results cannot be extrapolated to myocardial stunning which is defined as a completely reversible myocardial dysfunction, because in the present experimental model the contractile dysfunction was not reversible even after 2 hours of reoxygenation [38].

Several limitations must be considered when interpreting our results. First the effects of anesthetic drugs, diseases, or medical treatments received by the patients before obtaining atrial appendages cannot be ruled out. Furthermore, although our experimental groups showed comparable demographic data (table 1), age has been shown to impair ischemic PostC in senescent mouse hearts [39-41], and should also be considered in patients. Second, our experiments were performed under moderate hypothermia $\left(34^{\circ} \mathrm{C}\right)$ to ensure stability of trabeculae over time. However, during surgical procedures moderate hypothermia may occur. Third, blockade of adenosine receptors with SPT was not isoform specific, and we have investigated the role of ROS production using MPG. We did not directly measure ROS production nor the particular species of ROS. Fourth, as described in myocardial preconditioning, the beneficial effects of PostC have also been described on reperfusion-induced arrhythmias [42] and myocardial conctractility [43]. Fifth, we measured recovery of post hypoxic contractile function but not the infarct volume. However, it is not possible to precisely quantify the volume of necrosis in isolated trabeculae. Furthermore, it has been shown that the improved recovery of contractile function produced by preconditioning was proportional to reduced infarct size [44]. Finally, previous studies from our laboratories clearly showed that contractile dysfunction is a reliable parameter.

\section{Conclusion}

We have shown that stimulation of adenosine and bradykinin $B_{2}$ receptors and ROS generation, during early reoxygenation, were involved in desflurane-induced PostC in human myocardium, in vitro. Additionally, the cardioprotective effect of adenosine and bradykinin administered at the beginning of reoxygenation, was mediated, at least in part, through ROS production.

\section{Author details}

'Laboratory of Experimental Anesthesiology and Cellular Physiology, IFR 146 ICORE, Université de Caen Basse Normandie, CHU Caen, Avenue de la Cote de Nacre, 14033 Caen, France. ${ }^{2}$ Department of Anesthesiology, CHU Caen, Avenue de la Cote de Nacre, 14033 Caen, France. ${ }^{3}$ Department of cardiac and thoracic surgery, CHU Caen, Avenue de la Cote de Nacre, 14033 Caen, France.

\section{Authors' contributions}

$S L$ and JLH designed the investigation, reviewed the literature and drafted the manuscript. SL, GB, Cl, MM conducted the experiments. JLG, CB and RR contributed to the interpretation of the data.

All authors read and approved the manuscript.

\section{Competing interests}

The authors declare that they have no competing interests.

This work was supported by the Université de Caen Basse Normandie and Centre Hospitalier Universitaire de Caen.

Received: 14 March 2010 Accepted: 29 July 2010

Published: 29 July 2010

\section{References}

1. Obal D, Dettwiler S, Favoccia C, Scharbatke H, Preckel B, Schlack W: The influence of mitochondrial KATP-channels in the cardioprotection of preconditioning and postconditioning by sevoflurane in the rat in vivo. Anesth Analg 2005, 101:1252-60.

2. Deyhimy DI, Fleming NW, Brodkin IG, Liu H: Anesthetic preconditioning combined with postconditioning offers no additional benefit over 
preconditioning or postconditioning alone. Anesth Analg 2007, 105:316-24.

3. Tsutsumi YM, Yokoyama T, Horikawa Y, Roth DM, Patel HH: Reactive oxygen species trigger ischemic and pharmacological postconditioning: in vivo and in vitro characterization. Life Sci 2007, 81:1223-7.

4. Chiari PC, Bienengraeber MW, Pagel PS, Krolikowski JG, Kersten JR, Warltier DC: Isoflurane protects against myocardial infarction during early reperfusion by activation of phosphatidylinositol-3-kinase signal transduction: evidence for anesthetic-induced postconditioning in rabbits. Anesthesiology 2005, 102:102-9.

5. Krolikowski JG, Bienengraeber M, Weihrauch D, Warltier DC, Kersten JR, Pagel PS: Inhibition of mitochondrial permeability transition enhances isoflurane-induced cardioprotection during early reperfusion: the role of

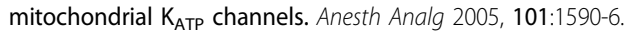

6. Lange M, Redel A, Lotz C, Smul TM, Blomeyer C, Frank A, Stumpner J, Roewer N, Kehl F: Desflurane-induced postconditioning is mediated by beta-adrenergic signaling: role of beta 1- and beta 2-adrenergic receptors, protein kinase $A$, and calcium/calmodulin-dependent protein kinase II. Anesthesiology 2009, 110:516-28.

7. Lemoine S, Beauchef $G$, Zhu L, Renard E, Lepage O, Massetti M, Khayat A, Galera P, Gérard JL, Hanouz JL: Signaling pathways involved in desflurane-induced postconditioning in human atrial myocardium in vitro. Anesthesiology 2008, 109:1036-44.

8. Yao YT, Li LH, Chen L, Wang WP, Li LB, Gao CQ: Sevoflurane postconditioning protects isolated rat hearts against ischemiareperfusion injury: the role of radical oxygen species, extracellular signal-related kinases $1 / 2$ and mitochondrial permeability transition pore. Mol Biol Rep 2010, 37:2439-46.

9. Burley DS, Baxter GF: Pharmacological targets revealed by myocardial postconditioning. Curr Opin Pharmacol 2009, 9:177-88.

10. Kin H, Zatta AJ, Lofye MT, Amerson BS, Halkos ME, Kerendi F, Zhao ZQ, Guyton RA, Headrick JP, Vinten-Johansen J: Postconditioning reduces infarct size via adenosine receptor activation by endogenous adenosine. Cardiovasc Res 2005, 67:124-33.

11. Penna C, Mancardi D, Rastaldo R, Losano G, Pagliaro P: Intermittent activation of bradykinin B2 receptors and mitochondrial KATP channels trigger cardiac postconditioning through redox signaling. Cardiovascular Research 2007, 75:168-77.

12. Roscoe AK, Christensen JD, Lynch C: Isoflurane, but not halothane, induces protection of human myocardium via adenosine $A 1$ receptors and adenosine triphosphate-sensitive potassium channels. Anesthesiology 2000, 92:692-701.

13. Kevin LG, Novalija E, Riess ML, Camara AK, Rhodes SS, Stowe DF: Sevoflurane exposure generates superoxide but leads to decreased superoxide during ischemia and reperfusion in isolated hearts. Anesth Analg 2003, 96:949-55.

14. Hanouz JL, Zhu L, Lemoine S, Durand C, Lepage O, Massetti M, Khayat A, Plaud B, Gérard JL: Reactive oxygen species mediate sevoflurane- and desflurane-induced preconditioning in isolated human right atria in vitro. Anesth Analg 2007, 105:1534-9.

15. Bell RM, Yellon DM: Bradykinin limits infarction when administered as an adjunct to reperfusion in mouse heart: the role of PI3K, Akt and eNOS. J Mol Cell Cardiol 2003, 35:185-93.

16. Müllenheim J, Ebel D, Frossdorf J, Preckel B, Thomer V, Schlack W: Isoflurane preconditions myocardium against infarction via release of free radicals. Anesthesiology 2002, 96:934-40.

17. Hanley PJ, Ray J, Brandt U, Daut J: Halothane, isoflurane and sevoflurane inhibit NADH: ubiquinone oxidoreductase (complex I) of cardiac mitochondria. J Physiol 2002, 544:687-93.

18. Ludwig LM, Tanaka K, Eells JT, Weihrauch D, Pagel PS, Kersten JR, Warltier DC: Preconditioning by isoflurane is mediated by reactive oxygen species generated from mitochondrial electron transport chain complex III. Anesth Analg 2004, 99:1308-15.

19. Sedlic F, Pravdic D, Ljubkovic M, Marinovic J, Stadnicka A, Bosnjak ZJ: Differences in production of reactive oxygen species and mitochondrial uncoupling as events in the preconditioning signaling cascade between desflurane and sevoflurane. Anesth Analg 2009, 109:405-11.

20. Tanaka K, Weihrauch D, Ludwig LM, Kersten JR, Pagel PS, Warltier DC: Mitochondrial adenosine triphosphate-regulated potassium channel opening acts as a trigger for isoflurane-induced preconditioning by generating reactive oxygen species. Anesthesiology 2003, 98:935-43.
21. Penna C, Mancardi D, Tullio F, Pagliaro P: Intermittent adenosine at the beginning of reperfusion does not trigger cardioprotection. J Surg Res 2009, 153:231-8.

22. Yang X, Philipp S, Downey J, Cohen M: Postconditioning's protection is not dependent on circulating blood factors or cells but involves adenosine receptors and requires PI3-kinase and guanylyl cyclase activation. Basic Res Cardiol 2005, 100:57-63.

23. Pagel PS: Postconditioning by volatile anesthetics: salvaging ischemic myocardium at reperfusion by activation of prosurvival signaling. Cardiothorac Vasc Anesth 2008, 22:753-65.

24. Morrison RR, Tan XL, Ledent C, Mustafa SJ, Hofmann PA: Targeted deletion of $A 2 A$ adenosine receptors attenuates the protective effects of myocardial postconditioning. Am J Physiol Heart Circ Physiol 2007, 293: H2523-9.

25. Donato M, D'Annunzio V, Berg G, Gonzalez G, Schreier L, Morales C, Wikinski RL, Gelpi RJ: Ischemic postconditioning reduces infarct size by activation of $\mathrm{A} 1$ receptors and $\mathrm{K}^{+}$(ATP) channels in both normal and hypercholesterolemic rabbits. J Cardiovasc Pharmacol 2007, 49:287-92.

26. Philipp S, Yang XM, Cui L, Davis AM, Downey JM, Cohen MV: Postconditioning protects rabbit hearts through a protein kinase Cadenosine A2b receptor cascade. Cardiovasc Res 2006, 70:308-14.

27. Xi L, Das A, Zhao ZQ, Merino VF, Bader M, Kukreja RC: Loss of myocardial ischemic postconditioning in adenosine $A 1$ and bradykinin $B 2$ receptors gene knockout mice. Circulation 2008, 118:S32-7.

28. Cope DK, Impastato WK, Cohen MV, Downey JM: Volatile anesthetics protect the ischemic rabbit myocardium from infarction. Anesthesiology 1997, 86:699-709.

29. Ismaeil MS, Tkachenko I, Gamperl AK, Hickey RF, Cason BA: Mechanisms of isoflurane-induced myocardial preconditioning in rabbits. Anesthesiology 1999, 90:812-21.

30. Kersten JR, Orth KG, Pagel PS, Mei DA, Gross GJ, Warltier DC: Role of adenosine in isoflurane-induced cardioprotection. Anesthesiology 1997, 86:1128-39.

31. Lu J, Zang WJ, Yu XJ, Jia B, Chorvatova A, Sun L: Effects of postconditioning of adenosine and acetylcholine on the ischemic isolated rat ventricular myocytes. Eur J Pharmacol 2006, 549:133-9.

32. Förster K, Paul I, Solenkova N, Staudt A, Cohen MV, Downey JM, Felix SB, Krieg T: NECA at reperfusion limits infarction and inhibits formation of the mitochondrial permeability transition pore by activating p70S6 kinase. Basic Res Cardiol 2006, 101:319-26.

33. Li Y, Sato T: Dual signaling via protein kinase $C$ and phosphatidylinositol 3'-kinase/Akt contributes to bradykinin B2 receptor-induced cardioprotection in guinea pig hearts. $\mathrm{J} \mathrm{Mol} \mathrm{Cell}$ Cardiol 2001, 33:2047-53.

34. Park SS, Zhao H, Mueller RA, Xu Z: Bradykinin prevents reperfusion injury by targeting mitochondrial permeability transition pore through glycogen synthase kinase 3beta. J Mol Cell Cardiol 2006, 40:708-16

35. Xu Z, Park SS, Mueller RA, Bagnell RC, Patterson C, Boysen PG: Adenosine produces nitric oxide and prevents mitochondrial oxidant damage in rat cardiomyocytes. Cardiovasc Res 2005, 65:803-12.

36. Cohen MV, Yang XM, Liu GS, Heusch G, Downey JM: Acetylcholine, bradykinin, opioids, and phenylephrine, but not adenosine, trigger preconditioning by generating free radicals and opening mitochondrial K(ATP) channels. Circ Res 2001, 89:273-8.

37. Couvreur N, Lucats L, Tissier R, Bize A, Berdeaux A, Ghaleh B: Differential effects of postconditioning on myocardial stunning and infarction: a study in conscious dogs and anesthetized rabbits. Am J Physiol Heart Circ Physiol 2006, 291:H1345-50.

38. Walker DM, Walker JM, Pugsley WB, Pattison CW, Yellon DM: Preconditioning in isolated superfused human muscle. J Mol Cell Cardiol 1995, 27:1349-57.

39. Lauzier B, Delemasure S, Debin R, Collin B, Sicard P, Acar N, Bretillon L, Joffre C, Bron A, Creuzot-Garcher C, Vergely C, Rochette L: Beneficial effects of myocardial postconditioning are associated with reduced oxidative stress in a senescent mouse model. Transplantation 2008, 85:1802-8.

40. Przyklenk K, Maynard M, Darling CE, Whittaker P: Aging mouse hearts are refractory to infarct size reduction with post-conditioning. J Am Coll Cardiol 2008, 51:1393-8.

41. Boengler K, Buechert A, Heinen Y, Roeskes C, Hilfiker-Kleiner D, Heusch G, Schulz R: Cardioprotection by ischemic postconditioning is lost in aged and STAT3-deficient mice. Circ Res 2008, 102:131-5. 
42. Dow J, Bhandari A, Kloner RA: Ischemic Postconditioning's Benefit on Reperfusion Ventricular Arrhythmias Is Maintained in the Senescent Heart. J Cardiovasc Pharmacol Ther 2008, 13:141-8.

43. Sivaraman V, Mudalagiri NR, Di Salvo C, Kolvekar S, Hayward M, Yap J, Keogh B, Hausenloy DJ, Yellon DM: Postconditioning protects human atrial muscle through the activation of the RISK pathway. Basic Res Cardiol 2007, 102:453-9.

44. Lasley RD, Anderson GM, Mentzer RM: Ischemic and hypoxic preconditioning enhance postischemic recovery of function in the rat heart. Cardiovasc Res 1993, 27:565-70.

\section{Pre-publication history}

The pre-publication history for this paper can be accessed here: http://www.biomedcentral.com/1471-2253/10/12/prepub

doi:10.1186/1471-2253-10-12

Cite this article as: Lemoine et al:: Bradykinin and adenosine receptors mediate desflurane induced postconditioning in human myocardium: role of reactive oxygen species. BMC Anesthesiology 2010 10:12.

\section{Submit your next manuscript to BioMed Central} and take full advantage of:

- Convenient online submission

- Thorough peer review

- No space constraints or color figure charges

- Immediate publication on acceptance

- Inclusion in PubMed, CAS, Scopus and Google Scholar

- Research which is freely available for redistribution

Submit your manuscript at www.biomedcentral.com/submit 